\title{
Predictors of discharge in child psychoanalytic psychotherapy
}

\author{
Preditores de alta em psicoterapia psicanalítica de crianças
}

Izabel Cristina Paez, ${ }^{1}$ Maria Lucia Tiellet Nunes, ${ }^{2}$ Vânia Naomi Hirakata ${ }^{3}$

\begin{abstract}
Introduction: This empirical study was based on the analysis of the results of a study about dropout predictors among in child psychoanalytic psychotherapy. The objectives were to characterize the sample of children discharged from psychoanalytic psychotherapy, examine the association between sociodemographic/clinical variables and child psychoanalytic psychotherapy discharge, and determine predictors of discharge in child psychoanalytic psychotherapy.

Method: This quantitative, descriptive and retrospective study analyzed the clinical records of 600 children treated in three institutions that offer graduate courses in psychoanalytic psychotherapy in Porto Alegre, Brazil.

Results: The analysis of clinical records revealed that $24.2 \%$ of the child patients were discharged from treatment. Neurological assessment and treatment duration were predictors of discharge in child psychoanalytic psychotherapy.

Conclusion: The predictors of discharge and dropout may coincide, but they are not the same. In this sample, the construction of the therapeutic alliance and the understanding of the reasons why children need psychotherapy by their parents or guardians may explain our findings.
\end{abstract}

Keywords: Patient discharge, psychotherapy, child, clinical psychology.

\section{Introduction}

A systematic review about discharge in child psychoanalytic psychotherapy has recently been conducted in the electronic databases INDEXPSI, LILACS, MEDLINE

\section{Resumo}

Introdução: Esta pesquisa empírica se baseou na análise dos resultados de um estudo sobre preditores de abandono de psicoterapia psicanalítica de crianças. Os objetivos foram caracterizar a amostra de crianças que recebeu alta em psicoterapia psicanalítica, examinar a relação entre variáveis sociodemográficas/ clínicas e alta em psicoterapia psicanalítica de crianças e averiguar preditores de alta em psicoterapia psicanalítica de crianças. Método: Trata-se de estudo quantitativo, descritivo, retrospectivo no qual foram analisados os registros de 600 prontuários de crianças atendidas em três instituições que oferecem cursos de pós-graduação em psicoterapia psicanalítica em Porto Alegre, RS, Brasil. Resultados: A análise dos prontuários indicou que $24,2 \%$ dos pacientes crianças receberam alta do tratamento. As variáveis avaliação neurológica e duração do tratamento foram identificadas como preditoras de alta em psicoterapia psicanalítica de crianças nesta amostra.

Conclusão: Os preditores de alta podem coincidir com aqueles de abandono, mas não são os mesmos. Nesta amostra, a construção da aliança terapêutica e o entendimento das razões pelas quais as crianças precisam de psicoterapia por parte de seus pais ou responsáveis foram consideradas como possíveis explicações para os resultados encontrados.

Descritores: Alta do paciente, psicoterapia, criança, psicologia clínica.

(PubMed), Psycinfo, PEPSIC and SciELO. ${ }^{1}$ The search term found for EMBASE was hospital discharge. Although different search terms were used, no studies about child psychoanalytic psychotherapy discharge were found in scientific journals. ${ }^{1}$ In the research group Assessment and

\footnotetext{
${ }^{1}$ Pontifícia Universidade Católica do Rio Grande do Sul (PUCRS), Porto Alegre, RS, Brazil. ${ }^{2}$ Professor, PUCRS, Porto Alegre, RS, Brazil. ${ }^{3}$ Hospital de Clínicas de Porto Alegre (HCPA), Porto Alegre, RS, Brazil.

Financial support: Scholarship Program for Master's and PhD Candidates (PROBOLSAS), Pontifícia Universidade Católica do Rio Grande do Sul (PUCRS). Submitted May 26 2014, accepted for publication Jan 25 2015. No conflicts of interest declared concerning the publication of this article.

Suggested citation: Paez IC, Nunes ML, Hirakata VN. Predictors of discharge in child psychoanalytic psychotherapy. Trends Psychiatry Psychother. $2015 ; 37(2): 67-71$. http://dx.doi.org/10.1590/2237-6089-2014-0020

This article is based on the dissertation entitled "Alta em psicoterapia psicanalítica de crianças" (Discharge in child psychoanalytic psychotherapy), presented in 2013 at the Graduate Program in Psychology, School of Psychology, Pontifícia Universidade Católica do Rio Grande do Sul (PUCRS), Porto Alegre, RS, Brazil.
} 
Intervention in Psychoanalytic Psychotherapy, which is coordinated by the second author as part of the Graduate Program in Psychology of the School of Psychology of the Pontifícia Universidade Católica do Rio Grande do Sul, Brazil, several studies about psychoanalytic psychotherapy have been conducted, and two of them were included in the present analysis. The first reviewed the literature to define treatment dropout, discuss the difficulty of defining dropout in various psychotherapeutic approaches, reflect on the criteria used in different definitions and suggest a definition of dropout in psychoanalytical psychotherapy. ${ }^{2}$ According to the authors, ${ }^{2}$ if the objectives determined in the psychotherapy agreement are reached, the patient may be included in the category of treatment discharge. ${ }^{2}$ The second study was an empirical evaluation of treatment dropout predictors that suggested that boys have a higher probability of not completing psychoanalytic psychotherapy, children in treatment for less than six months have a higher probability of treatment dropout, and those referred by neurologists or psychologists have a lower probability of treatment dropout. ${ }^{3}$ The analysis of results led to the hypotheses that variables such as sex, referral source, and treatment duration might be discharge predictors in child psychoanalytic psychotherapy. Therefore, these variables were selected as the key themes for our study.

The objectives of this study were: to describe the clinical and sociodemographic characteristics of the sample of children that achieved psychoanalytic psychotherapy discharge; to investigate the association between child psychoanalytic psychotherapy discharge and sociodemographic variables (age, sex, family structure, education); to investigate the association between child psychoanalytic psychotherapy discharge and clinical variables (reasons for treatment, referral source, treatment duration, psychological and neurological assessment); and to investigate which clinical and sociodemographic variables of psychoanalytic psychotherapy predict child discharge.

\section{Method}

This retrospective quantitative-descriptive study was approved by the Research Ethics Committee of the Graduate Program in Psychology, School of Psychology, Pontifícia Universidade Católica do Rio Grande do Sul, Porto Alegre, Brazil (protocol no. 027/2012 - FCC).

\section{Participant selection and description}

The study sample comprised data retrieved from the clinical records of 600 child patients undergoing psychoanalytic psychotherapy and entered into a database analyzed using the Statistical Package for the Social Sciences (SPSS) version 13 during two previous studies: one to evaluate predictors of treatment dropout ${ }^{3}$; and the other, to analyze problems of child development. ${ }^{4}$ The same data were also used in a study about nonadherence to treatment. ${ }^{5}$ Clinical and sociodemographic variables of child patients that received psychoanalytic psychotherapy in three institutions in Porto Alegre, southern Brazil, between the years of 1979 and 2009, were collected after their parents or guardians signed an informed consent form. The three institutions included in the study, Contemporâneo - Instituto de Psicanálise e Transdisciplinaridade, Centro de Estudos e Atendimento de Psicoterapia da Infância e Adolescência (CEAPIA) and Estudos Integrados de Psicoterapia Psicanalítica (ESIPP), offer graduate courses in psychoanalytic psychotherapy. ${ }^{3-5}$ Inclusion criteria were: 12 years or younger, as the classification as children is defined in the Statute of Children and Teenagers ${ }^{6}$ in Brazil; type of treatment outcome; sex of child patient; referral source; and treatment duration. The following records were excluded:

- Patient older than 12 years, one record $(0.045 \%)$;

- No data about referral source, 239 records (10.86\%);

- No data about treatment duration, 163 records (7.4\%);

- Nonadherence to treatment, 299 records (13.60\%);

- Data about treatment attendance continuation, 163 records (7.4\%);

- Data about patient referral, 1 record (0.045\%);

- No data about treatment termination, 731 records (33.22\%);

- No data about type of treatment indicated, 3 records $(0.13 \%)$.

\section{Technical information}

During data collection for the original studies, 3,4 the authors found that various terms were used to record the reasons for treatment and define treatment termination. Reasons for treatment were recorded in three different instances: 1) description of reasons given by the parents or guardians during the initial interview or entered in the form completed during the first contact with the institutions; 2) information entered in the evaluation form during the first contact of the patient with the professional responsible for the initial interview in the institution; 3) information entered in the psychological assessment records by the child's psychotherapist. The first, second and third reasons for treatment referral on the clinical charts were added to the database. ${ }^{3}$ Data were clinically analyzed first individually and then by pairs of observers 
and grouped according to the eight scales of the Child Behavior Checklist (CBCL) developed by Achenbach (in Gastaud \& Nunes, ${ }^{3}$ Boaz et al., ${ }^{4}$ Gastaud et al. ${ }^{5}$ ). There were many records about learning difficulties, and an extra category had to be created to describe that information..$^{3-5}$ Briefly: 1) anxiety/depression (cries, fears, does not feel loved); 2) constraint/ depression (bashful, sad, prefers to be alone); 3) somatic complaints (dizziness, tiredness, nausea, headache); 4) relationship problems (does not get along well with people, is dependent, people tease him/her); 5) thought problems (hears voices, sees things, weird behaviors) 6) attention problems (does not concentrate, is very agitated, daydreams); 7) challenging behaviors (vandalism, thefts, lies, etc.); 8) aggressive behavior (fights, screams, arguments, etc.); 9) learning problems (grade failure, difficulty in a subject, etc.) (Achenbach in Gastaud \& Nunes, ${ }^{3}$ p. 16; Achenbach in Boaz et al., ${ }^{4}$ p. 336; and Achenbach in Gastaud et al., ${ }^{5}$ p. 111).

Data about the type of treatment termination, as recorded by the psychotherapists in the database used for the studies about predictors of treatment dropout ${ }^{3}$ and child development problems, ${ }^{4}$ were classified according to psychoanalytical psychotherapy discharge records of the three institutions. Discharge occurred when the treatment objectives, determined in the psychotherapeutic contract, were reached. ${ }^{3}$

\section{Statistics}

A chi-square test $\left(X^{2} ; p<0.05\right)$ was used to ensure that no specific type of patient was excluded, that is, that the sample was homogeneous and not affected by the fact that $1,600(72.7 \%)$ clinical records of the database that originated this study sample were excluded. The $x^{2}$ test $(p<0.05)$ was also used to compare data about discharge and dropout in the selected sample, and multivariate Poisson regression with robust variance estimation $(p<0.05)$ was used to analyze the independent associations of variables that resulted in psychotherapy discharge.

\section{Results}

In the sample of 600 clinical records of child patients undergoing psychoanalytical psychotherapy, there were 145 discharge records (24.2\%) and 455 dropout records $(75.8 \%)$. Sample homogeneity and the characteristics of the child patients that completed psychoanalytical psychotherapy and were discharged are shown in Tables 1 and 2.
Table 1 - Sociodemographic and clinical characteristics (\%) and sample homogeneity

\begin{tabular}{|c|c|c|}
\hline Variable & $\begin{array}{l}\text { Database } \\
(\mathbf{n}=\mathbf{2}, \mathbf{2 0 0})\end{array}$ & $\begin{array}{l}\text { Sample } \\
(n=600)\end{array}$ \\
\hline \multicolumn{3}{|l|}{ Sex } \\
\hline Male & 65.5 & 67.8 \\
\hline Female & 34.5 & 32.2 \\
\hline \multicolumn{3}{|l|}{ Age } \\
\hline $0-4.5$ years & 9.9 & 8.7 \\
\hline $4.6-6.5$ years & 18.5 & 18.3 \\
\hline $6.6-8.5$ years & 29.4 & 32.5 \\
\hline $8.6-10.5$ years & 25.4 & 23.8 \\
\hline $10.6-11.11$ years & 16.8 & 16.7 \\
\hline \multicolumn{3}{|l|}{ Schooling } \\
\hline Kindergarten & 23.1 & 23.4 \\
\hline 1st-4th grade & 65.3 & 65.7 \\
\hline 5th-7th grade & 11.6 & 10.9 \\
\hline \multicolumn{3}{|l|}{ Family structure } \\
\hline Two parents & 61.8 & 64.2 \\
\hline Single parent & 21.8 & 20.2 \\
\hline $\begin{array}{l}\text { Mother and father with another } \\
\text { relative }\end{array}$ & 11.7 & 11.1 \\
\hline Others & 4.9 & 4.4 \\
\hline \multicolumn{3}{|l|}{ Reasons for treatment } \\
\hline Anxiety/depression & 16.6 & 15.5 \\
\hline Treatment constraint/depression & 6.7 & 6.0 \\
\hline Somatic complaints & 6.5 & 6.7 \\
\hline Relationship problems & 11.4 & 11.8 \\
\hline Thought problems & 3.5 & 2.8 \\
\hline Attention problems & 16.3 & 14.7 \\
\hline Rule-breaking behavior & 4.6 & 4.7 \\
\hline Aggressive behavior & 21.7 & 22.0 \\
\hline Learning problems & 12.6 & 15.8 \\
\hline \multicolumn{3}{|l|}{ Referral source } \\
\hline Parent(s) & 10.5 & 12.7 \\
\hline School & 42.6 & 46.8 \\
\hline Pediatrician & 31.8 & 28.3 \\
\hline Psychologist & 15.1 & 12.2 \\
\hline \multicolumn{3}{|l|}{ Treatment duration } \\
\hline Only triage & 8.0 & 0 \\
\hline Less than a month & 13.7 & 0 \\
\hline 1-6 months & 37.1 & 55.1 \\
\hline 7-12 months & 12.9 & 20.2 \\
\hline $13-24$ months & 10.9 & 16.3 \\
\hline 25-36 months & 3.0 & 5.2 \\
\hline$>37$ months & 2.2 & 3.2 \\
\hline Still under treatment & 12.2 & 0 \\
\hline \multicolumn{3}{|l|}{ Psychological assessment } \\
\hline Yes & 17.7 & 18.9 \\
\hline No & 82.3 & 81.1 \\
\hline \multicolumn{3}{|l|}{ Neurological assessment } \\
\hline Yes & 25.3 & 25.6 \\
\hline No & 74.7 & 74.4 \\
\hline
\end{tabular}


Table 2 - Sociodemographic and clinical characteristics of the children that were discharged

\begin{tabular}{|c|c|}
\hline Variable & Discharge (\%) \\
\hline \multicolumn{2}{|l|}{ Sex } \\
\hline Male & 22.9 \\
\hline Female & 26.9 \\
\hline \multicolumn{2}{|l|}{ Age } \\
\hline $0-4.5$ years & 25.5 \\
\hline 4.6-6.5 years & 21.8 \\
\hline $6.6-8.5$ years & 25.6 \\
\hline $8.6-10.5$ years & 22.4 \\
\hline $10.6-11.11$ years & 25.7 \\
\hline \multicolumn{2}{|l|}{ Schooling } \\
\hline Kindergarten & 22.5 \\
\hline 1st-4th grade & 25.5 \\
\hline 5 th-7th grade & 28.6 \\
\hline \multicolumn{2}{|l|}{ Family structure } \\
\hline Two parents & 25.2 \\
\hline Single parent & 21.7 \\
\hline Mother and father with another relative & 24.2 \\
\hline Others & 15.4 \\
\hline \multicolumn{2}{|l|}{ Reasons for treatment } \\
\hline Anxiety/depression & 28.0 \\
\hline Treatment constraint/depression & 22.2 \\
\hline Somatic complaints & 20.0 \\
\hline Relationship problems & 26.8 \\
\hline Thought problems & 29.4 \\
\hline Attention problems & 23.9 \\
\hline Challenging behavior & 17.9 \\
\hline Aggressive behavior & 22.0 \\
\hline Learning problems & 25.3 \\
\hline \multicolumn{2}{|l|}{ Referral source } \\
\hline Parent(s) & 19.7 \\
\hline School & 22.1 \\
\hline Pediatrician & 25.9 \\
\hline Psychologist & 32.9 \\
\hline \multicolumn{2}{|l|}{ Treatment duration } \\
\hline 1-6 months & 10.3 \\
\hline 7-12 months & 32.2 \\
\hline 13-24 months & 45.9 \\
\hline 25-36 months & 54.8 \\
\hline$>37$ months & 52.6 \\
\hline \multicolumn{2}{|l|}{ Psychological assessment } \\
\hline Yes & 35.0 \\
\hline No & 23.9 \\
\hline \multicolumn{2}{|l|}{ Neurological assessment } \\
\hline Yes & 34.5 \\
\hline No & 21.2 \\
\hline
\end{tabular}

Psychotherapy discharge was not associated with the following variables: sex $\left(X^{2}=1.197\right.$, degrees of freedom [df] $=1, p=0.274)$; age $\left(x^{2}=0.998, d f=4, p=\right.$ $0.910)$; schooling $\left(X^{2}=0.820, d f=2, p=0.664\right)$; family structure $\left(X^{2}=1.719, d f=3, p=0.633\right)$; reasons for treatment $\left(X^{2}=2.721, d f=8, p=0.951\right)$; and referral source $\left(X^{2}=4.787, d f=3, p=0.188\right)$. Psychotherapy discharge was associated with treatment duration $\left(X^{2}=\right.$ 88.779, $d f=4, p=0.000)$; psychological assessment $\left(x^{2}\right.$ $=5.277, \mathrm{df}=1, \mathrm{p}=0.022) ;$ and neurological assessment $\left(x^{2}=10.408, d f=1, p=0.001\right)$, but the results of Poisson regression revealed that only neurological assessment and treatment duration were predictors of discharge in psychoanalytical psychotherapy of children in this sample. Neurological assessment prevalence was 1.33 (95\% confidence interval [95\%CI] 1.003-1.77), that is, children that underwent previous neurological assessment had a $33 \%$ greater probability of reaching psychotherapy discharge than those that did not ( $p=$ 0.047 ). Poisson regression results also revealed that the prevalence of children treated for more than 37 months was 4.8 (95\%CI 2.77-8.27), and they had a four times greater probability of achieving psychotherapy discharge than children treated from one to six months $(p<0.001)$.

\section{Discussion}

This study sample was selected from a database built for three other studies, with different objectives, ${ }^{3-5}$ and a detailed discussion about the sociodemographic and clinical characteristics of the sample may be found in two of them: the one that investigated child development disorders ${ }^{4}$; and the one that evaluated predictors of treatment dropout. ${ }^{3}$ The percentage of psychotherapy discharge in this study about predictors (24.2\%) was almost identical to the $24 \%$ of patients discharged in the study conducted by Midgley \& Navridi, ${ }^{7}$ also cited in the study about predictors of treatment dropout. ${ }^{3}$ The percentage of discharge was three times lower than the dropout rate in these two studies of child patients undergoing psychoanalytical psychotherapy.

Of the three variables suggested by the results of the study conducted by Gastaud \& Nunes, ${ }^{3}$ only treatment duration was confirmed as a predictor of discharge. The higher percentage of discharge was found in the group of children whose treatment lasted 25 to 30 months. This result was similar to that reported in the study conducted by Midgley \& Navridi. ${ }^{7}$ The highest percentage of children discharged was found in the group that received psychoanalytical treatment for more than 24 months, ${ }^{7}$ a finding also reported in the study about predictors of treatment dropout, ${ }^{3}$ which suggests that the therapeutic 
alliance was constructed during treatment. According to Lhulier et al., ${ }^{8}$ the interactional bond between patient and therapist, a fundamental element of therapy success that remains to be studied, may demand more time, ${ }^{3}$ as parents also participate in the work alliance in the outpatient clinics where their study was carried out. ${ }^{8}$

The other two variables suggested by the findings of the study about treatment dropout predictors, ${ }^{3}$ sex and the referral source, were not confirmed as predictors of discharge in this study. However, the analysis of the characteristics of the sample in this study revealed that the highest percentage of children that were discharged was referred by psychologists. Before initiating psychotherapy, the need of other clinical assessments, by a pediatrician, ophthalmologist, otolaryngologist, audiologist, psycho-educator or neurologist, as well as the need to apply psychological tests, should be determined still during the phase of assessment if the child symptoms allow. ${ }^{9}$

Although previous psychological assessment was not a predictor, it may contribute to patient discharge because it may confirm that the causes of symptoms are psychological and that psychotherapy should be indicated. ${ }^{3}$ The children referred by psychologists may have undergone psychological assessment that indicated the need for psychotherapy, which may help parents or guardians understand the reasons why their children should undergo a psychotherapeutic treatment. ${ }^{3}$ The continuity of child psychotherapy depends on parental motivation, ${ }^{10}$ and the results of previous neurological and psychological assessments may make it clear for parents or guardians that the child needs treatment, which may keep children in treatment up to its completion and discharge.

\section{Conclusion}

The predictors of discharge and dropout may coincide, but they are not all the same. The results of neurological assessment, a predictor of discharge in this study, as well as of psychological assessment, may help parents and guardians understand the reasons why their children need psychotherapy. The construction of the psychotherapeutic alliance with parents and guardians may favor treatment duration, ${ }^{3}$ another predictor of discharge according to our findings.

\section{References}

1. Paez IC, Nunes ML. Considerações sobre alta de crianças após triagem e a definição de alta em psicoterápica psicanalítica de crianças. Rev Bras Psicoter. 2013;15:75-96.

2. Gastaud MB, Nunes ML. Abandono de tratamento na psicoterapia psicanalítica: em busca de definição. J Bras Psiquiatr. 2010;59:247-54.

3. Gastaud MB, Nunes ML. Preditores de abandono de tratamento na psicoterapia psicanalítica de crianças. Rev Psiquiatr Rio Gd Sul. 2009;31:13-23.

4. Boaz C, Nunes ML, Hirakata VN. A problemática do desenvolvimento de crianças assistidas por clínicas-escola brasileiras mudaram no decorrer das décadas? Psico. 2012;43:334-40.

5. Gastaud MB, Basso F, Soares JP, Eizirik CL, Nunes ML. Preditores de não aderência ao tratamento na psicoterapia psicanalítica de crianças. Rev Psiquiatr Rio Gd Sul. 2011;33:109-15

6. Brasil, Código Civil. Lei Federal 8.069. Diário Oficial da União, 13 de julho de 1990. http://www.planalto.gov.br/ccivil_03/leis/ I8069compilado.htm

7. Midgley N, Navridi E. An exploratory study of premature termination in child analysis. J Infant Child Adolesc Psychother. 2006;5:437-58.

8. Lhullier AC, Nunes ML, Antochevis AF, Porto AM, Figueiredo D. Mudança de terapeuta e abandono da psicoterapia em uma clínica-escola. Aletheia. 2000;11:7-11.

9. Zavaschi ML, Conte C, Recondo R, Bassols AM, Ghelen M. Psicoterapia de orientação analítica na infância. In: Cordioli AV, editor. Psicoterapia abordagens atuais. Porto Alegre: Artmed; 2008. p.697-715.

10. Deakin EK, Nunes ML. Abandono de psicoterapia com crianças. Rev Psiquiatr Rio Gd Sul. 2009;31:145-51.

\section{Correspondence:}

Izabel Cristina Paez

Rua Portugal, 92, Jardim Europa

87111-050 - Sarandi, PR - Brazil

Tel. : + 55 (44) 9963-9076 / + 55 (51) 8280-3594

E-mail: izabelcristinapaez@hotmail.com 